\title{
Accelerated ageing as a vigour test on chickpea seeds
}

\author{
Letícia Betânia Xavier Dias ${ }^{1}$, Pedro Afonso de Melo Queiroz ${ }^{1}$, Lara Bernardes da Silva Ferreira ${ }^{1}$, Marco \\ Antônio Moreira de Freitas ${ }^{1}$, Érica Fernandes Leão-Araújo ${ }^{1^{*}}$, Patrícia Pereira da Silva ${ }^{2}$, Warley Marcos \\ Nascimento $^{2}$
}

\author{
${ }^{1}$ Instituto Federal Goiano, Rodovia Geraldo Silva Nascimento, km 2.5, Zona Rural, 75790-000 - Urutaí, GO \\ - Brasil \\ ${ }^{2}$ Embrapa Hortaliças, Núcleo Rural Vargem da Benção, Gama, Caixa Postal 280, 70275-970 - Brasília, DF, \\ Brasil
}

*Corresponding author: erica.leao@ifgoiano.edu.br

\section{Abstract}

The objective of this work was to establish the temperature and the period of exposure needed to perform the traditional accelerated ageing test with saturated $\mathrm{NaCl}$ salt solution on chickpea seeds. Eight seed lots from two cultivars, including four seeds each, were subjected to germination and vigour tests for initial characterization. Following the methodology of the traditional accelerated ageing test. The seeds were placed on stainless steel screens in boxes with $40 \mathrm{~mL}$ deionized water. They were kept at 41 and $45^{\circ}$ Celsius for 24 and 48 hours. Furthermore, the accelerated ageing test using $40 \mathrm{~g} \mathrm{of} \mathrm{NaCl}$ in $100 \mathrm{~mL}$ of water, thus providing $76 \%$ of relative humidity in air] $\mathrm{NaCl}$ (salt) solution in place of the deionized water was performed. Aged seeds were sowed in germination paper and kept in a germination chamber at 41 o and 450 Celsius. The evaluations were performed five and eight days after sowing. The statistical analysis was performed with a completely randomized design and four replications. The traditional ageing of both cultivars showed a water content higher than the tolerated limits at 48 hour period and 41 and $45^{\circ} \mathrm{C}$. In the saturated saline test, the cultivar BRS Aleppo produced consistent results at temperatures $45{ }^{\circ} \mathrm{C}$ for $24 \mathrm{~h}$. The cultivar Cícero showed a low correlation with the initial characterization as the results of accelerated ageing. Thus, for 'BRS Aleppo', the recommended accelerated ageing methodology was application of saturated saline solution, when seed exposed to $41{ }^{\circ} \mathrm{C}$ for 24 hours with germination evaluation at the first count date. For 'Cicero', satisfactory results were not obtained, and new studies are required to establish a methodology.

Keywords: Cicer arietinum L.; germination; legume; saline solution; vigour.

Abbreviations: AA_Accelerated ageing; AASS_accelerated ageing with saturated saline solution; Cor_Pearson correlation; CIM_coincidence index of the means tests; ESI_emergence speed index; FC_germination first count; G_germination; GSI_germination speed index; $h \_$hours; LC_evaluations in the last count, eight days after sowing; MC_seed moisture content; MET_mean emergence time; SE_seedlings emergence on field; SL_seedlings length; SL-AP_seedlings length of the aerial part; SLRS_ seedlings length of the root system; SL-T_total seedlings length; ${ }^{\circ} \mathrm{C}$ _degrees Celsius; TSW_thousand seeds weight.

\section{Introduction}

Chickpea (Cicer arietinum L.) is a highly nutritious legume and an excellent source of protein, carbohydrates, minerals, vitamins, and fiber (Santos et al., 2017). It also has better digestibility than other grains and a low content of antinutritional substances. It is estimated that 11.6 million tons of this grain are produced annually in the world, especially in developing countries (ICRISAT, 2018).

In Brazil there has been an increase in the consumption of chickpeas over the last 10 years, mainly due to the high protein content. According to Paula Júnior and Venzon (2007), the main form of consumption in Brazil is as whole grains cooked and served in the form of salad or pasta. According to Hoskem et al. (2017), despite being a cold climate plant, the chickpea adapts well to tropical regions like Brazil, producing crops with good development and high productivity.
World production of chickpeas has only marginally increased over the last three decades due to the decline in planted area, while productivity has increased by around $37 \%$ over the same period. The increasing productivity of this legume is due to improvements in the cultivation, which includes research on the material used in planting, as well as cultivation techniques (Nascimento et al., 2016). The choice of high quality seeds directly influences the satisfactory establishment of the plants in the field and, consequently, high productivity indexes.

One of the aspects that interferes with the productivity of the crops is the of plants in the field. Among many factors, population of depends depends on the quality of the seeds. In order to establish storage, commercialization, and quality control policies, seed companies have used the results of vigour tests in conjunction with germination tests for 
decision making, especially in the comparison of lots (Martins et al., 2014).

Among the tests that evaluate the physiological quality of the seeds, we have the accelerated ageing test, which is a commonly used test of vigour. It has been successfully used for soybean seeds (Marcos-Filho, 1999; Dutra and Vieira, 2004), corn (Fessel et al., 2006), and other species such as crambe (Leão et al., 2016). In this test, the seeds are subjected to high temperature and relative humidity for a relatively short period and then placed to germinate. Lots of high-vigour seeds will remain viable after being submitted to these conditions, while those of low vigour will have their viability reduced (Nascimento et al., 2014; Marcos-Filho, 2015). Thus, the temperature used and the time of exposure to this temperature are factors that influence the quality of the results generated by the test.

The use of saturated salt solution in alternative acceleration ageing methodologies aims to reduce the relative humidity of the air during the exposure of the seeds to high temperatures. The effect of this reduction is the slower rate of water uptake and consequently a reduction in seed deterioration (Jianhua and McDonald, 1996; Panobianco and Marcos-Filho, 2001). This alternative has been recommended for evaluation of several species such as tomato (Panobianco and Marcos-Filho, 2001), coriander (Radke et al., 2016), and rice (Monteiro et al., 2017).

The objective of this study was to establish an efficient methodology to perform the traditional accelerated ageing test (with water) and alternative test with saturated $\mathrm{NaCl}$ salt solution ( $76 \%$ relative humidity in air) to determine the optimal period and temperature of exposure for chickpea seeds.

\section{Results and Discussion}

\section{Physiological characterization of the seed lots}

Table 1 shows the data obtained in the initial physiological characterization tests. For 'BRS Aleppo', the germination first count (FC) ranked the lots in four levels, as the most sensitive test to detect differences in the vigour of this cultivar. The FC was also efficient to identify differences in the vigour of lots of okra seeds, as reported by Torres et al. (2014), which compared FC with germination and seedling emergence tests. The FC test is recommended for evaluating the seed vigour of several species such as Cucumis melo L. (Bhering et al., 2004) and Beta vulgaris L. (Silva and Vieira, 2006). The efficiency of the test can be explained, according to Marcos-Filho (2015), by the fact that one of the first expressions of the process of seed deterioration is the reduction of the germination process speed. In the $G$, SE and ESI tests, there was a distinction in three levels of vigour, in which lot 1 was classified as the best and lot 3 the worst. In the SL-RS, lots were classified into two levels. Finally, the MET and SL-AP and SL-T tests did not rank the vigour levels of seed lots and were not efficient in classifying them. In general, after initial characterization, lot 1 had the most vigour, followed by lots 4 and 2 as intermediates and lot 3 with the worst performance. In the case of the Cícero cultivar, the ESI was the test that efficiently classified the lots, resulting in three levels. As with FC, the ESI test evaluates the speed of the germination process, which is strongly affected by the physiological state of the seeds, i.e. deteriorating seeds will take more time to complete germination process tasks (Marcos-Filho, 2015). In Sorghum bicolor L. Moench Ullmann et al. (2015), used ESI as a method to evaluate the effect of temperatures during the drying of seeds, observing satisfactory results with the use of this test.

The FC, G, SE and SL tests ranked the lots within two levels, with lot 2 having higher vigour (Table 1). The MET test did not rank the lots at vigour levels. Therefore, according to the tests, lot 2 presented better results, while lots 1 and 3 had worse performance.

Initial seed moisture content and after the variations of $A A$ tests

The seed moisture content of the seeds directly influenced several aspects of its physiological quality. Therefore, its determination is fundamental in quality tests of seed lots (Sarmento et al., 2015). Thus, the determination of the initial seed moisture content and moisture content after the ageing of the seeds guarantees the reliability of the vigour tests. The initial seed moisture content should not vary by more than 2.0 percentage points between lots (MarcosFilho, 2015), which was the variation obtained in this experiment (Table 2) for both cultivars. After the ageing of the seeds, the same variation is expected according to Marcos-Filho (2015). In our study, this variation was exceeded at $45{ }^{\circ} \mathrm{C}$ for 48 hours of exposure for both cultivars, which makes it difficult to recommend these variables. For this same period, the variation was slightly higher than 2.0 percentage points at $41{ }^{\circ} \mathrm{C}$. The higher values of $\mathrm{MC}$ were observed at $45^{\circ} \mathrm{C}$ compared $\mathrm{t} 41^{\circ} \mathrm{C}$. This finding can be explained by the fact that, at higher temperatures, the kinetic energy of the system is high so there is greater absorption of water by the seeds (Dias and Marcos-Filho, 1995). The MC obtained after AASS were lower than those found with AA (Table 3). Using the methodology with saturated saline solution, the relative humidity is reduced from $100 \%$ to $76 \%$ (Jianhua and McDonald, 1996). Thus, the deterioration rates of seeds are reduced compared to the AA test, due to the lower water absorption. This test could simulate moisture conditions during seed storage (Peñaloza et al., 2005). In AASS the seed moisture content after ageing test met the maximum variation of 2.0 percentage points suggested by Marcos-Filho (2015), ensuring consistency of results.

\section{Thousand seeds weight}

The TSW test revealed that the seeds of the cultivar Cícero are substantially larger than the seeds of the BRS Aleppo cultivar (Table 4). The seeds of the lot 1 of the Cícero cultivar presented TSW approximately twice as large as seeds of the lot 2 of 'BRS Aleppo'. The characteristics of the cultivars are the results of the crosses and/or selections made by breeding programs. The size of the seeds may vary between cultivars and influence in several aspects such as the physiological quality of the seeds.

\section{Accelerated ageing - traditional and with saturated saline solution}

The cultivar BRS Aleppo showed the best overall performance of accelerated ageing (AA), considering the temperatures of 41 and $45 \stackrel{\circ}{ } \mathrm{C}$ for the periods of $24 \mathrm{~h}$ and 48 
Table 1. Initial characterization of seed lots of chickpea seeds by germination first count (FC), germination (G), seedlings emergence on field (SE), speed emergence index (ESI), average time of emergence (MET), seedling length (SL) - aerial part (SL-AP), root system (SL-RS) and total (SL-T). Urutaí, 2017.

\begin{tabular}{|c|c|c|c|c|c|c|c|c|c|c|c|c|c|c|c|c|}
\hline \multicolumn{17}{|c|}{ 'BRS Aleppo' } \\
\hline \multirow[t]{2}{*}{ Seed lot } & \multicolumn{2}{|l|}{$\mathrm{FC}$} & \multicolumn{2}{|l|}{$G$} & \multicolumn{2}{|l|}{ SE } & \multicolumn{2}{|l|}{ ESI } & \multicolumn{2}{|l|}{ MET } & SL-AP & \multicolumn{3}{|c|}{ SL-RS } & \multicolumn{2}{|l|}{ SL-T } \\
\hline & & & $\%$ & & & & & & _days & & & $\mathrm{cm}$ & eedling & & & \\
\hline 1 & $\overline{86.0}$ & $a^{*}$ & 94.0 & $\mathrm{a}$ & 95.0 & a & 14.7 & a & 16.9 & a & 16.0 & $a$ & 14.3 & a & 20.3 & a \\
\hline 2 & 56.5 & $C$ & 79.0 & $b$ & 73.5 & $\mathrm{bc}$ & 11.6 & bc & 26.7 & $\mathrm{a}$ & 6.0 & a & 11.4 & $b$ & 17.3 & a \\
\hline 3 & 43.0 & $D$ & 52.5 & c & 65.0 & c & 9.9 & c & 37.2 & $a$ & 4.9 & a & 11.5 & $b$ & 16.3 & $\mathrm{a}$ \\
\hline 4 & 72.5 & B & 88.0 & $a b$ & 88.0 & $a b$ & 13.3 & $a b$ & 47.1 & $\mathrm{a}$ & 5.4 & $a$ & 11.1 & $b$ & 16.4 & $\mathrm{a}$ \\
\hline CV (\%) & 9.83 & & 8.19 & & 13.18 & & 15.18 & & 4.85 & & 12.73 & & 12.37 & & 11.36 & \\
\hline \multicolumn{17}{|l|}{ 'Cícero' } \\
\hline \multirow[t]{2}{*}{ Seed lot } & $\mathrm{FC}$ & & G & & SE & & ESI & & MET & & SL-AP & & SL-RS & & SL-T & \\
\hline & & & $\%$ & & & & & & _days & & & $\mathrm{cm}$ & eedling & & & \\
\hline 1 & 20.0 & $\mathrm{~b}$ & 48.0 & $\mathrm{~b}$ & 72.0 & $a b$ & 7.9 & $b c$ & 9.7 & $a$ & 3.4 & $\mathrm{~b}$ & 7.9 & $\mathrm{~b}$ & 11.3 & $\mathrm{~b}$ \\
\hline 2 & 42.5 & a & 76.5 & a & 81.0 & $a b$ & 9.6 & a & 9.0 & $a$ & 4.4 & a & 10.2 & $a$ & 14.6 & a \\
\hline 3 & 35.5 & $a$ & 55.5 & $b$ & 63.0 & $b$ & 7.3 & c & 9.4 & $a$ & 3.3 & b & 8.9 & $a b$ & 12.2 & $\mathrm{~b}$ \\
\hline 4 & 18.0 & $b$ & 59.5 & $b$ & 76.5 & $a b$ & 9.1 & $a b$ & 9.0 & $\mathrm{a}$ & 3.2 & $b$ & 8.5 & $b$ & 11.7 & $b$ \\
\hline CV (\%) & 22.30 & & 15.44 & & 10.32 & & 13.20 & & 8.08 & & 14.00 & & 11.00 & & 7.50 & \\
\hline
\end{tabular}

*Means followed by the same letter in the column do not differ by the LSD test at $10 \%$ probability.

Table 2. Initial seed moisture content and after traditional accelerated ageing under two temperatures $\left(41\right.$ and $\left.45^{\circ} \mathrm{C}\right)$ and two exposure periods ( 24 and 48 hours). Urutaí, 2017.

\begin{tabular}{|c|c|c|c|c|c|}
\hline \multirow{3}{*}{ Seed lot } & & \multicolumn{4}{|c|}{ 'BRS Aleppo' } \\
\hline & \multirow[b]{2}{*}{ Initial } & \multicolumn{2}{|l|}{$41^{\circ} \mathrm{C}$} & \multicolumn{2}{|l|}{$45^{\circ} \mathrm{C}$} \\
\hline & & 24 hours & 48 hours & 24 hours & 48 hours \\
\hline 1 & 9.63 & 17.14 & 21.19 & 18.83 & 25.35 \\
\hline 2 & 10.04 & 17.71 & 22.12 & 20.49 & 25.45 \\
\hline 3 & 10.06 & 17.56 & 21.94 & 18.93 & 24.92 \\
\hline \multirow[t]{2}{*}{4} & 9.71 & 16.94 & 23.72 & 20.12 & 22.42 \\
\hline & & \multicolumn{4}{|c|}{ ‘Cícero' } \\
\hline \multirow[t]{2}{*}{ Seed lot } & & $41^{\circ} \mathrm{C}$ & & $45^{\circ} \mathrm{C}$ & \\
\hline & Initial & 24 hours & 48 hours & 24 hours & 48 hours \\
\hline 1 & 8.80 & 15.78 & 19.47 & 17.32 & 23.19 \\
\hline 2 & 9.30 & 16.50 & 21.69 & 17.14 & 20.03 \\
\hline 3 & 9.07 & 17.79 & 19.63 & 16.00 & 24.46 \\
\hline 4 & 9.33 & 16.71 & 19.17 & 15.33 & 25.71 \\
\hline
\end{tabular}

Table 3. Initial seed moisture content and after accelerated ageing with saturated saline under two temperatures ( 41 and $45^{\circ} \mathrm{C}$ ) and two exposure periods ( 24 and 48 hours). Urutaí, 2017.

\begin{tabular}{|c|c|c|c|c|c|}
\hline \multirow{3}{*}{ Seed lot } & \multicolumn{4}{|c|}{ 'BRS Aleppo' } & \\
\hline & \multirow[b]{2}{*}{ Initial } & \multicolumn{2}{|l|}{$41^{\circ} \mathrm{C}$} & \multicolumn{2}{|l|}{$45^{\circ} \mathrm{C}$} \\
\hline & & 24 hours & 48 hours & 24 hours & 48 hours \\
\hline 1 & 9.63 & 12.12 & 14.02 & 13.09 & 13.54 \\
\hline 2 & 10.04 & 12.28 & 13.95 & 12.57 & 15.20 \\
\hline 3 & 10.06 & 12.20 & 13.02 & 12.13 & 14.76 \\
\hline \multirow[t]{2}{*}{4} & 9.71 & 12.16 & 13.07 & 12.13 & 14.89 \\
\hline & & \multicolumn{4}{|l|}{ 'Cícero' } \\
\hline \multirow[t]{2}{*}{ Seed lot } & & $41^{\circ} \mathrm{C}$ & & $45^{\circ} \mathrm{C}$ & \\
\hline & Initial & 24 hours & 48 hours & 24 hours & 48 hours \\
\hline 1 & 8.80 & 11.50 & 12.47 & 12.32 & 13.83 \\
\hline 2 & 9.30 & 11.59 & 13.22 & 13.41 & 13.59 \\
\hline 3 & 9.07 & 11.54 & 13.34 & 12.46 & 14.12 \\
\hline 4 & 9.33 & 11.80 & 13.78 & 12.72 & 13.41 \\
\hline
\end{tabular}


Table 4. Thousand seeds weight (TSW) of seed lots of chickpea seeds, BRS Aleppo and Cícero cultivars. Urutaí, 2017.

\begin{tabular}{llc}
\hline Seed lot & & TSW (g) \\
\hline & 'BRS Aleppo' & 'Cícero' \\
1 & 382.43 & 648.30 \\
2 & 344.29 & 542.55 \\
3 & 384.73 & 476.27 \\
4 & 390.99 & 595.67 \\
\hline
\end{tabular}

Table 5. Germination after exposure of chickpea seeds to the traditional accelerated ageing test under two temperatures (41 $1^{\circ}$ and $45^{\circ} \mathrm{C}$ ) and two exposure periods ( 24 and 48 hours). Germination evaluated on the date of the first count (FC) and on the date of the final count (LC). Urutaí, 2017.

\begin{tabular}{|c|c|c|c|c|c|c|c|c|c|c|c|c|c|c|c|c|}
\hline \multirow{4}{*}{ Seed lot } & \multicolumn{16}{|c|}{ 'BRS Aleppo' } \\
\hline & \multicolumn{8}{|l|}{$41^{\circ} \mathrm{C}$} & \multicolumn{8}{|l|}{$45^{\circ} \mathrm{C}$} \\
\hline & \multicolumn{4}{|c|}{24 hours } & \multicolumn{4}{|c|}{48 hours } & \multicolumn{4}{|c|}{24 hours } & \multicolumn{4}{|c|}{48 hours } \\
\hline & $\mathrm{FC}$ & & LC & & $\mathrm{FC}$ & & $\mathrm{LC}$ & & FC & & $\mathrm{LC}$ & & $\mathrm{FC}$ & & $\mathrm{LC}$ & \\
\hline 1 & 58.00 & a* & 93.50 & $a$ & 70.00 & $a$ & 87.50 & $a$ & 87.00 & $a$ & 95.00 & $a$ & 79.50 & $a$ & 90.00 & $a$ \\
\hline 2 & 50.00 & $a$ & 64.00 & $b$ & 44.00 & $b$ & 63.00 & $b$ & 55.00 & $b$ & 69.00 & $b$ & 49.50 & $b$ & 52.50 & $\mathrm{c}$ \\
\hline 3 & 21.50 & $\mathrm{~b}$ & 34.50 & c & 14.00 & c & 21.00 & c & 25.50 & c & 32.00 & c & 27.50 & c & 29.50 & $d$ \\
\hline 4 & 43.50 & a & 70.00 & $\mathrm{~b}$ & 42.00 & $b$ & 60.00 & $\mathrm{~b}$ & 58.50 & $b$ & 76.00 & $a b$ & 57.00 & $\mathrm{~b}$ & 68.50 & $\mathrm{~b}$ \\
\hline \multirow[t]{3}{*}{ CV (\%) } & 16.43 & & 12.01 & & 13.58 & & 13.34 & & 22.79 & & 17.57 & & 11.10 & & 10.79 & \\
\hline & \multicolumn{16}{|c|}{ 'Cícero' } \\
\hline & $41^{\circ} \mathrm{C}$ & & & & & & & & $45^{\circ} \mathrm{C}$ & & & & & & & \\
\hline \multirow[t]{2}{*}{ Seed lot } & \multicolumn{4}{|c|}{24 hours } & \multicolumn{4}{|c|}{48 hours } & \multicolumn{4}{|c|}{24 hours } & \multicolumn{4}{|c|}{48 hours } \\
\hline & $\mathrm{FC}$ & & LC & & $\mathrm{FC}$ & & LC & & FC & & $\mathrm{LC}$ & & $\mathrm{FC}$ & & LC & \\
\hline 1 & 6.50 & $b$ & 34.00 & $b$ & 19.00 & $a b$ & 40.50 & $a$ & 29.50 & $b$ & 57.50 & $b$ & 19.50 & $a$ & 33.50 & c \\
\hline 2 & 9.00 & $b$ & 49.50 & $a$ & 27.50 & $\mathrm{a}$ & 53.50 & $a$ & 59.50 & $\mathrm{a}$ & 87.50 & $\mathrm{a}$ & 32.00 & $\mathrm{a}$ & 59.50 & $\mathrm{a}$ \\
\hline 3 & 18.50 & a & 51.50 & $a$ & 16.50 & $\mathrm{~b}$ & 46.00 & $a$ & 31.50 & $b$ & 66.00 & $b$ & 33.00 & $a$ & 52.50 & $a b$ \\
\hline 4 & 13.00 & $a b$ & 54.50 & $\mathrm{a}$ & 10.50 & $b$ & 36.50 & a & 45.50 & $a b$ & 69.50 & $a b$ & 20.50 & $\mathrm{a}$ & 35.50 & bc \\
\hline CV (\%) & 30.88 & & 14.94 & & 26.89 & & 22.14 & & 18.72 & & 13.88 & & 23.74 & & 18.36 & \\
\hline
\end{tabular}

Table 6. Germination after exposure of chickpea seeds to the accelerated ageing test with saturated saline under two temperatures ( 41 and $45^{\circ} \mathrm{C}$ ) and two exposure periods ( 24 and 48 hours). Germination evaluated on the date of the first count (FC) and on the date of the final count (LC). Urutaí, 2017.

\begin{tabular}{|c|c|c|c|c|c|c|c|c|c|c|c|c|c|c|c|c|}
\hline \multirow{4}{*}{ Seed lot } & \multicolumn{16}{|c|}{ 'BRS Aleppo' } \\
\hline & \multicolumn{8}{|l|}{$41^{\circ} \mathrm{C}$} & \multicolumn{8}{|l|}{$45^{\circ} \mathrm{C}$} \\
\hline & \multicolumn{4}{|c|}{24 hours } & \multicolumn{4}{|c|}{48 hours } & \multicolumn{4}{|c|}{24 hours } & \multicolumn{4}{|c|}{48 hours } \\
\hline & FC & & $\mathrm{LC}$ & & FC & & $\mathrm{LC}$ & & $\mathrm{FC}$ & & LC & & $\mathrm{FC}$ & & LC & \\
\hline 1 & 79.00 & a* & 91.00 & $a$ & 76.50 & $a$ & 92.50 & $a$ & 86.50 & $a$ & 96.50 & $a$ & 87.00 & $a$ & 97.00 & $a$ \\
\hline 2 & 72.50 & $a b$ & 80.00 & $a b$ & 42.50 & bc & 64.50 & $b$ & 57.50 & $b$ & 79.50 & b & 62.50 & $b$ & 77.00 & $b$ \\
\hline 3 & 42.50 & c & 48.00 & C & 27.00 & c & 40.50 & C & 28.00 & c & 42.50 & c & 40.50 & $c$ & 49.50 & $c$ \\
\hline 4 & 58.00 & $\mathrm{bc}$ & 73.50 & $\mathrm{~b}$ & 46.50 & $b$ & 68.50 & $\mathrm{~b}$ & 67.50 & $\mathrm{~b}$ & 89.50 & $a b$ & 71.00 & $\mathrm{~b}$ & 88.50 & $a b$ \\
\hline \multirow[t]{3}{*}{ CV (\%) } & 12.24 & & 9.66 & & 16.33 & & 15.51 & & 9.46 & & 7.54 & & 8.18 & & 7.82 & \\
\hline & \multicolumn{16}{|c|}{ ‘Cícero' } \\
\hline & $41^{\circ} \mathrm{C}$ & & & & & & & & $45^{\circ} \mathrm{C}$ & & & & & & & \\
\hline \multirow[t]{2}{*}{ Seed lot } & \multicolumn{4}{|c|}{24 hours } & \multicolumn{4}{|c|}{48 hours } & \multicolumn{4}{|c|}{24 hours } & \multicolumn{4}{|c|}{48 hours } \\
\hline & $\mathrm{FC}$ & & LC & & $\mathrm{FC}$ & & $\mathrm{LC}$ & & FC & & LC & & $\mathrm{FC}$ & & LC & \\
\hline 1 & 24.00 & $b$ & 46.00 & $b$ & 15.50 & $a$ & 46.00 & $a$ & 33.50 & bc & 58,50 & $a$ & 31,00 & $a$ & 59,50 & $b$ \\
\hline 2 & 45.00 & a & 74.00 & $a$ & 20.00 & a & 64.50 & $a$ & 41.00 & $a b$ & 82,50 & a & 49,50 & $a$ & 77,00 & $a$ \\
\hline 3 & 27.00 & $b$ & 54.00 & $b$ & 13.00 & a & 51.00 & $a$ & 46.00 & $a b$ & 68,00 & a & 41,00 & $a$ & 61,50 & $b$ \\
\hline 4 & 26.50 & b & 67.50 & $a$ & 20.00 & a & 54.50 & $a$ & 28.50 & C & 72,00 & a & 40,00 & $a$ & 62,00 & $\mathrm{~b}$ \\
\hline CV (\%) & 12.89 & & 9.69 & & 33.33 & & 19.44 & & 15.38 & & 11.95 & & 15.84 & & 9.25 & \\
\hline
\end{tabular}

*Means followed by the same letter in the column do not differ by the LSD test at $10 \%$ probability. 
Table 7. Pearson correlation coefficient (Cor) and coincidence percentage index of the means tests (CIM). Correlations between seedlings emergence in the field (SE) and traditional accelerated ageing (AA) tests and accelerated ageing with saturated salt solution (AASS) under two temperatures $\left(41\right.$ and $45{ }^{\circ} \mathrm{C}$ ) and two exposure periods (24 and 48 hours). Germination evaluated on the date of the first count (FC) and on the date of the final count (LC). Urutaí, 2017.

\begin{tabular}{|c|c|c|c|c|c|c|c|c|}
\hline & \multicolumn{4}{|c|}{ 'BRS Aleppo' } & \multicolumn{4}{|c|}{ ‘Cícero' } \\
\hline & \multicolumn{8}{|c|}{ Period (hours) } \\
\hline & \multicolumn{2}{|l|}{24} & \multicolumn{2}{|l|}{48} & \multicolumn{2}{|l|}{24} & \multicolumn{2}{|l|}{48} \\
\hline & $\mathrm{FC}$ & LC & $\mathrm{FC}$ & LC & $\mathrm{FC}$ & LC & $\mathrm{FC}$ & $\mathrm{LC}$ \\
\hline & \multicolumn{8}{|c|}{$41^{\circ} \mathrm{C} A \mathrm{~A}$} \\
\hline Cor & 0.71 & 0.76 & 0.72 & 0.72 & -0.44 & 0.00 & 0.25 & 0.16 \\
\hline \multirow[t]{2}{*}{ CIM (\%) } & 50 & 100 & 100 & 100 & 50 & 25 & 50 & 50 \\
\hline & \multicolumn{8}{|c|}{$41^{\circ} \mathrm{C}$ AASS } \\
\hline Cor & 0.35 & 0.53 & 0.53 & 0.63 & 0.31 & 0.44 & 0.26 & 0.22 \\
\hline \multirow[t]{2}{*}{$\mathrm{CIM}(\%)$} & 100 & 100 & 100 & 100 & 25 & 25 & 50 & 50 \\
\hline & \multicolumn{8}{|c|}{$45^{\circ} \mathrm{C} A \mathrm{~A}$} \\
\hline Cor & 0.71 & 0.74 & 0.66 & 0.69 & 0.29 & 0.16 & -0.20 & -0.03 \\
\hline \multirow[t]{2}{*}{ CIM (\%) } & 100 & 100 & 100 & 75 & 25 & 25 & 50 & 25 \\
\hline & \multicolumn{8}{|c|}{$45^{\circ} \mathrm{C}$ AASS } \\
\hline Cor & 0.74 & 0.72 & 0.63 & 0.65 & -0.20 & 0.49 & 0.49 & 0.48 \\
\hline CIM (\%) & 100 & 100 & 100 & 100 & 25 & 50 & 50 & 25 \\
\hline
\end{tabular}

hours and the analysis of FC and LC (Table 5). Then Lot 4 and 2 had an intermediate performance and Lot 3 the lowest in all cases. The results showed classification of the lots in three vigour levels, except for the FC at 41 oc for $24 \mathrm{~h}$, in which only two levels of vigor were obtained. For FC at 45 으 for $48 \mathrm{~h}$, the lots were classified into four vigour levels, similar to the classification found in the initial characterization. Similarly, Leão et al. (2016) reported that crambe seeds should be exposed to $41{ }^{\circ} \mathrm{C}$ for $48 \mathrm{~h}$ in the AA test.

For Cícero cultivar, Lot 2 showed the best performance, except for $\mathrm{FC}$ at $41{ }^{\circ} \mathrm{C}$ for $24 \mathrm{~h}$. Lots 3 and 4 were generally classified as intermediary performances, with some differences in rank. Finally, lot 1 presented the worst performance compared to others.

In most cases, the lots distinction was occurred in only two vigour levels in $\mathrm{FC}$, except for $41^{\circ} \mathrm{C}$ and $45^{\circ} \mathrm{C}$ for $48 \mathrm{~h}$. On the other hand, the $\mathrm{FC}$ at $45{ }^{\circ} \mathrm{C}$ for $48 \mathrm{~h}$ showed three levels of vigour ranking of the lots. This classification with some small differences is similar with that initial characterization. Similar results were found by Silva and Cícero (2014) with tomato seeds, in which the initial characterization tests classified the lots differently from the classification obtained in accelerated ageing tests. This can be explained by the definition of vigour. According to ISTA (2014): a set of properties will determine the performance of lots under wide range of environmental conditions. Therefore, using a single test or tests that are based on the same principles that affect seed performance cannot generate complete information about seed quality, according to Hampton and Coolbear (1990).

The germination of the seeds submitted to the AASS presented the same tendency obtained for AA, differing in some points. For the cultivar BRS Aleppo, lot 1 showed better performance in all cases, lot 4 soon followed in intermediate position along with lot 2 , and finally lot 3 , which under all conditions had the worst performance (Table 6). There was a three-level strength ranking for all variations in the AASS test with BRS Aleppo cultivar, a classification that matches the results obtained in the initial characterization tests.
With the exposure to saturated saline solution, the lot 2 of cultivar Cícero showed the best performance, excluding only one case for $\mathrm{FC}$ at 45 으 for 24 hours, in which this lot was classified as intermediate, as well as lot $3\left(41^{\circ} \mathrm{C}\right.$ for $48 \mathrm{~h}$ in $\mathrm{FC}$ and LC; $45^{\circ} \mathrm{C}$ for $24 \mathrm{~h}$ in FC; and $45^{\circ} \mathrm{C}$ for $48 \mathrm{~h}$ in FC). The others classified the lots at only two levels $\left(41^{\circ} \mathrm{C}\right.$ for $24 \mathrm{~h}$ in $\mathrm{FC}$ and LC, $45^{\circ} \mathrm{C}$ for $24 \mathrm{~h}$ in FC and $45^{\circ} \mathrm{C}$ for $48 \mathrm{~h}$ in LC). Only in one case, the classification showed three levels of vigour (45 oC per $24 \mathrm{~h}, \mathrm{FC}$ ). However, for this cultivar, the classification was not similar to the results obtained in the initial characterization.

The larger seed size of the Cícero cultivar (Table 4) may be responsible for the low efficiency of the accelerated ageing tests to detect the vigour of the lots. Jianhua and McDonald (1996) reported that seed size can interfere with accelerated ageing. Larger seeds may exhibit variations in water absorption during ageing, as well as variations in the effect of temperature along the whole seed length, influencing the level of deterioration reached by the seeds of the sample during the test. Consequently, it also affects the efficiency of these tests in ranking seed lots for vigor levels.

\section{Variables association}

Pearson correlation (Cor) and coincidence index of the means (CIM) results are available in Table 7. For 'BRS Aleppo' $\mathrm{CIM}$ values were high, mainly in AASS. Using as a criterion, the highest values for Cor and CIM was observed for the AA test, which is best correlated with SE when performed at 41 ${ }^{\circ} \mathrm{C}$ for $24 \mathrm{~h}$ in LC and for $48 \mathrm{~h}$ in FC and LC. One of the requirements of the vigour tests is that they are fast. For agile decision making by the seed industries, the variable 41 ${ }^{\circ} \mathrm{C}$ for $48 \mathrm{~h}$ and evaluation in the $\mathrm{FC}$ would be the best alternative for the AA test. However, changes in seed moisture content, before and after exposure to $A A$, greater than 2 percentage points (Table 2 ) precluded the recommendation of this test. Similar results were obtained by Gordin et al. (2015), which did not recommend the use of the traditional method in Guizotia abyssinica seeds because it provides variation of the seed moisture content between the samples greater than the tolerable standard. 
For the AASS test, the temperature of $45{ }^{\circ} \mathrm{C}$ for $24 \mathrm{~h}$ and evaluation in both FC and LC were the most consistent. Following the criterion of agility, the best option is the evaluation in the FC. These results agree with those obtained by Leão et al. (2016) studying the AASS test for crambe seeds. The authors concluded that $24 \mathrm{~h}$ at 41 or 45 ${ }^{\circ} \mathrm{C}$ is best to determine vigour in this species. These authors also agreed that post-ageing assessment is best performed on the date of the first count.

The results for the cultivar Cicero did not present the same tendency, as the values of CIM were low. In addition, results were found to be null or negative for Cor, due to the fact that there was no relation between the SE test in the initial characterization and the AA. This may also be due to the effect of seed size on the efficiency of ageing procedures, as discussed earlier. Amaro et al. (2014), used the Pearson correlation methodology in crambe seeds. They also reported the absence of correlation between combinations of the accelerated ageing test and those of the other initial characterization tests that had been useful in the stratification of lots for vigour and initial quality assessment tests.

\section{Materials and Methods}

\section{Plant material}

Four lots of chickpea (Cicer arietinum L.) of BRS Aleppo cultivar and four of cultivar Cícero were used. Before the beginning of the experiments the seeds were stored in a 'kraft' paper bag in a cold room $\left(16{ }^{\circ} \mathrm{C}\right.$ and $50 \%$ of relative humidity in air) for one month. The research was conducted at the Federal Institute Goiano, Campus Urutaí, Laboratory of Seed Analysis.

\section{Initial characterization of the seed lots}

Routine tests for physical and physiological characterization of seeds were initially developed to allow comparison with the variables of accelerated aging tests. For the initial characterization of the lots, the tests described below were conducted:

Seed moisture content (MC): determined by the oven-drying method at $105 \pm 3$ ㅇ C for $24 \mathrm{~h}$ (Brasil, 2009), using two subsamples of approximately $10.0 \mathrm{~g}$ of seeds for each lot. The results were expressed as percentage (wet basis). It was carried out initially to characterize the lots and after each variable of the tests of traditional accelerated ageing and with saturated saline solution.

Thousand seeds weight (TSW): the mass of eight replicates of 100 seeds of each lot were obtained (Brasil, 2009). The variance, standard deviation and coefficient of variation were calculated for each lot. With coefficient of variation values lower than $4 \%$, the mean weight was multiplied by 10 and the results were expressed in grams.

Germination (G): for each lot, four replicates of 50 seeds were randomly assigned to the portion of pure seeds, arranged under two sheets of germinating paper and another sheet over the seeds, and then rolled up. The papers were previously moistened with water the equivalent of 3.0 times the weight of the dry substrate. The rolls were conditioned in a germinator at constant temperature of 20 ${ }^{\circ} \mathrm{C}$. After the five-day period the data of germination first count (FC) were obtained, and eight days after sowing, data of final germination (G) were obtained (Brasil, 2009). The results were expressed as a percentage of normal seedlings. Seedlings Length (SL): four replicates of 10 seeds, in longitudinal direction, were placed in the upper $1 / 3$ of the germination paper. The papers were moistened as described for the germination test. The seeds were positioned so that the radicle region was facing the bottom of the paper. The rolls were kept under the same conditions mentioned for the germination test. Eight days after sowing, measurements of the emergent normal seedlings (aerial part [AP] and root system [RS]) were carried out using a digital caliper. The sum of SL-AP and SL-RS was called SL-T, which revealed the average total length of normal seedlings. The results were expressed in centimeters.

Seedlings emergence on field (SE): a sprinkler irrigation system was used on the field. Four replications of 50 seeds per lot were sown so that the seeds remained at $3.0 \mathrm{~cm}$ depth, arranged in a soil bed without fertilization in lines of $2.5 \mathrm{~m}$ of length and spaced $0.5 \mathrm{~m}$. A hypocotyl greater than $1 \mathrm{~cm}$ in length at the time of the evaluation (21 days) was adopted as an evaluation criterion for determining the percentage of emerged normal seedlings.

Emergence speed index (ESI): calculated at the end of the SE test, using the formula proposed by Maguire (1962). Performed together with the SE test with seedling counting every $72 \mathrm{~h}$ until the 21st day, considering the number of seedlings that presented the cotyledons above the soil surface.

Mean emergence time (MET): values were expressed in days and obtained from the formula of Labouriau (1983), with the same data obtained for ESI.

\section{Adaptation of the accelerated aging test methodology - traditional and saturated saline solution}

To adapt the accelerated ageing test methodology, as a method to evaluate the vigour of chickpea seeds, the lots were submitted to the following tests:

Accelerated ageing (AA): the seeds were distributed in a single layer on the stainless-steel screen, placed in a Gerbox type box with $40 \mathrm{~mL}$ deionized water at the bottom and kept in an ageing chamber. The seed boxes remained at 41 and $45 \stackrel{\circ}{ } \mathrm{C}$ for 24 and $48 \mathrm{~h}$. After these periods, four replicates of 50 seeds were used for the germination test as described previously. The evaluations were performed at five (FC) and eight days (LC) after sowing and the results expressed as a percentage of normal seedlings. Accelerated ageing with saturated saline solution (AASS): The same procedure described for conducting the traditional procedure was used, except that the $40 \mathrm{~mL}$ volume of deionized water was replaced with $\mathrm{NaCl}$ salt solution (Jianhua and McDonald, 1996). This solution was obtained by diluting $40 \mathrm{~g}$ of $\mathrm{NaCl}$ in $100 \mathrm{~mL}$ of water, thus providing $76 \%$ of relative humidity in air. Evaluations were also performed with five (FC) and eight days (LC) and the results expressed as a percentage of normal seedlings.

\section{Statistical analysis}

The initial physiological characterization tests were installed separately for each cultivar and the analysis performed individually for each test (FC, G, SL, SE, ESI and MET). They were installed in a completely randomized design with four 
replicates. The residues were tested with the Shapiro-Wilk (for normality) and Bartlett tests (homoscedasticity). The data were submitted to analysis of variance by the F-test. For comparison of the means, the LSD test was used, at $10 \%$ probability.

In the interest of the accuracy of the AA and AASS methodologies, the tests were set up separately for each cultivar and the analysis performed individually for each variation of the methodology: temperature, exposure period and period to evaluate. The residues were tested with the Shapiro-Wilk (for normality) and Bartlett tests (homoscedasticity). The data were submitted to analysis of variance by the F-test. For comparison of the means, the LSD test was used at $10 \%$ probability.

To compare the initial characterization more precisely, the test of SE with each methodological variation of the AA, and tests of association of the variables were performed. The test for association for the variables was analyzed using the Pearson correlation (Cor) and the coincidence index of the means tests (CIM) in percentage, between the variables of AA or AASS tests and SE. This percentage was calculated as follows: $0 \%$ was used when no letter was matched between AA or AASS and SE tests and $100 \%$ when all letters of the mean tests were the same, comparing AA or AASS with SE. All analyzes were performed using the $\mathrm{R}$ software ( $\mathrm{R}$ Core Team, 2014).

\section{Conclusions}

For BRS Aleppo cultivar, the recommended accelerated ageing methodology to evaluate seed vigour is the use of saturated saline solution, with the seed exposure for $24 \mathrm{~h}$ at $41{ }^{\circ} \mathrm{C}$ and germination evaluation at the first count data, at five days after sowing. As for Cicero cultivar, satisfactory results were not obtained, and new studies are required in order to establish a methodology.

\section{Acknowledgment}

To the Federal Institute Goiano - campus Urutaí, for granting scientific scholarship.

\section{References}

Amaro HTR, David AMS de S, Neta ICS, Assis M de $\mathrm{O}$, Araújo EF, Araújo RF (2014) Accelerated ageing test in seeds of crambe (Crambe abyssinica Hochst), cultivar FMS Brilhante. Rev Ceres. 61:202-208.

Bhering MC, Dias DCFS, Tokuhisa D, Dias LAS (2004) Avaliação do vigour de sementes de melão pelo teste de deterioração controlada. Rev Bras de Sementes. 26:125129.

BRASIL. MAPA (Ministério da Agricultura, Pecuária e Abastecimento, Secretaria de Defesa Agropecuária) (2009) Regras para análise de sementes. Mapa/ACS, Brasília. 399p.

Dias DCSF, Marcos Filho J (1995) Testes de vigor baseados na permeabilidade das membranas celulares: II. Lixiviação de potássio. Informativo ABRATES. 5:37-41.

Dutra AS, Vieira RD (2004) Envelhecimento acelerado como teste de vigor para sementes de milho e soja. Cienc Rural. 34:715-721.
Fessel SA, Vieira RD, Cruz MCP, Paula RC, Panobianco M (2006) Electrical conductivity testing of corn seeds as influenced by temperature and period of storage. Pesqui Agropecu Bras. 41:1551-1559.

Gordin CRB, Scalon S de PQ, Masetto TE (2015) Accelerated ageing test in niger seeds. J Seed Sci. 37:234-240.

Hampton JG, Coolbear P (1990) Potential versus actual seed performance can vigour testing provide an answer. Seed Sci Technol. 18:215-228.

Hoskem BCS, Costa CA, Nascimento WM, Santos LDT, Mendes RB, Menezes JB de C (2017) Productivity and quality of chickpea seeds in Northern Minas Gerais, Brazil. Rev Bras Cienc Agr. 12:261-268.

ICRISAT - International Crops Research Institute for the SemiArid Tropics (2018) Chickpea. http://www.icrisat.org/ what-we-do/crops/ChickPea/Chickpea.htm. 14 Aug. 2018.

ISTA - International Seed Test Association (2014) Seed vigour testing. In: International Rules for Seed Testing. Bassersdorf, Zurich, 15.

Jianhua Z, McDonald MB (1996) The saturated salt accelerated ageing test for small-seeded crops. Seed Sci Technol. 25:123-131.

Labouriau LG (1983) A germinação de sementes. Secretaria geral da Organização dos Estados Americanos, Washington. 174p.

Leão EF, Santos, JF dos, Barbosa RM, Vieira RD (2016) Accelerated ageing as a vigour test for crambe (Crambe abyssinica) seeds. Aust J Crop Sci. 10:660-665.

Maguire JD (1962) Speed of germination aid in selection and evaluation for seedling emergence and vigour. Crop Sci. 2: 176-177.

Marcos-Filho J (2015) Physiology of cultivated plant seeds. Abrates, Londrina. 660p.

Marcos-Filho J (1999) Teste de envelhecimento acelerado. In: Krzyzanowski FC, Vieira RD, França Neto JB (eds) Vigour de sementes: conceitos e testes. Abrates, Londrina. 3.

Martins CC, Silva N da, Machado CG (2014) Testes para a seleção de populações de cenoura visando ao vigour e à longevidade das sementes. Cienc Rural. 44:768-774.

Monteiro DT, Tunes LM, Pacheco C, Lemes ES, Almeida AS, Muniz MFB (2017) Envelhecimento acelerado e ocorrência de fungos para avaliação do potencial fisiológico de sementes de arroz. Rev Cienc Agrar. 40:94-104.

Nascimento WM, Silva PP da, Artiaga OP, Suinaga FA (2016) Grão-de-bico. In: Nascimento WM (ed) Hortaliças Leguminosas. Embrapa, Brasília. 3.

Nascimento WM, Silva PP da, Freitas RA de (2014) Produção de sementes de ervilha. In: Nascimento WM (ed) Produção de sementes de hortaliças. Embrapa, Brasília. 6.

Panobianco M, Marcos-Filho J (2001) Envelhecimento acelerado e deterioração controlada em semente de tomate. Sci Agric. 58:525-531.

Paula-Junior TJ de, Venzon M (2007) 101 culturas: manual de tecnologias agrícolas. EPAMIG, Belo Horizonte. 800p.

Peñaloza P, Ramirez-Rosale SG, McDonald MB, Benett MA (2005) Lettuce (Lactuca sativa L.) seed quality evaluation using seed physical attributes, saturated salt accelerated ageing and the seed vigour imageing system. Electron J Biotechn. 8:299-307.

R CORE TEAM (2014) R: A language and environment for statistical computing. $\mathrm{R}$ Foundation for Statistical Computing, Vienna. http://www.Rproject.org/. 26 Aug. 2018. 
Radke AK, Reis BB, Gewehr E, Almeida AS, Tunes LM, Villela FA (2016) Alternativas metodológicas do teste de envelhecimento acelerado em sementes de coentro. Cienc Rural. 46:95-99.

Santos IHV da S, Souza IC de F, Silva SCB da, Nascimento KP da SM, Oliveira TW de, Lima EMC, Souza SFN de (2017) Análise nutricional e de aceitabilidade de empada à base de grão-de-bico, com recheio de frango e pupunha. Saber Cient. 6:26-34.

Sarmento HG dos S, David AMS de S, Barbosa MG, Nobre DAC, Amaro HTR (2015) Determinação do teor de água em sementes de milho, feijão e pinhão-manso por métodos alternativos. Energ Agric. 30:249-256.
Silva VN, Cicero SM (2014) Image seedling analysis to evaluate tomato seed physiological potential. Cienc Agron. 45:327-334.

Silva JB, Vieira RD (2006) Avaliação do potencial fisiológico de sementes de beterraba. Rev Bras Sementes. 28:128134.

Torres SB, Silva FG da, Gomes MD de A, Benedito CP, Pereira FECB, Silva EC da (2017) Diferenciação de lotes de sementes de quiabo pelo teste de envelhecimento acelerado. Cienc Rural. 44:2103-2110.

Ullmann R, Resende O, Chaves TH, Oliveira DEC de, Costa LM (2015) Qualidade fisiológica das sementes de sorgo sacarino submetidas à secagem em diferentes condições de ar. Rev Bras Eng Agric Ambient. 19:64-69. 